Associate professor, PhD Lilia Y. Abramchik, Head of the Department of a constitutional law, Yanka Kupala State University of Grodno, Republic of Belarus

Associate professor, PhD Sviatlana Ahiyevets, Director, Institute of Advanced Training and Professional Retraining, Yanka Kupala State University of Grodno, Republic of Belarus

\title{
SCIENTIFIC JOURNALS OF THE REPUBLIC OF BELARUS IN WHICH RESULTS OF SCIENTIFIC ACHIEVEMENTS OF LEGAL RESEARCHERS CAN BE PUBLISHED
}

$\mathrm{I}$ $\mathrm{n}$ the Republic of Belarus the development of scientific and innovative researches is reflected in scientific journals in order to improve the quality of training of highly qualified scientific experts in accordance with the strategic directions to ensure a unified state policy in the field of state certification of scientific and pedagogical staff.

Instruction about the formation order of the list of scientific editions of the Republic of Belarus for the publication of dissertations research results was approved by the Decree of the Higher Attestation Commission of the Republic of Belarus of June 8, 2009 № 3 (as amended by the decree of the Higher Attestation Commission of Belarus of June 30, 2012 № 5).

This legal act establishes requirements for scientific publications in which the results of scientific research can be published. A periodical included in the list must meet the following requirements:

- before the publication will be released on the list, its release is carried out not less than one year preceding the date of submission of the necessary materials to the Higher Attestation Commission of the Republic of Belarus (hereinafter - HAC) for inclusion on the list of editions;

- in the edition scientific articles publish the results of research carried out in different organizations;
- in the edition scientific articles are published in not more than in three branches of science (three research areas);

- in the edition in which besides scientific articles are published other materials is allocated the rubric "scientific publications";

- editorial board and editorial council of the edition is headed by a Doctor of Science. It is allowed to take the post of a chairman of the editorial board and editorial council by the Candidate of Science under the condition that the deputy of the chairman of the editorial board and the editorial council is the Doctor of Science;

- in the edition scientific articles must pass independent review of the Doctors or Candidates of science who are appointed by the editorial board, editorial council and the chief editor. Review submitted to the editorial board should disclose the relevance, importance and scientific-theoretical, methodological and practical value of the article, contain an assessment of presented scientific results and validity of the conclusions;

- scientific articles of the edition must publish information about the date of their admission to the editorial board and also about the place of work of their authors;

- published scientific articles are accompanied by annotation (summary) in one of the state languages 
of the Republic of Belarus and in English, as well as comply with other requirements determined by HAC for publications on the subject of the dissertation in the form of scientific articles;

- the edition has a ISSN code (International Standard Serial Number) and conforms to the requirements defined by the second part of this paragraph;

- circulation of the edition is not less than 100 copies;

- mandatory free copies of publications distributed in order established by the Regulation for the compulsory free copies of the documents approved by the Resolution of the Council of Ministers of September 3, 2008 № 1284 (National Register of Legal Acts of the Republic of Belarus, 2008, № 222, 5/28290);

- the edition is included in the catalog for subscription to the print media in accordance with the Rules of acccapting a subscription to the print media and its delivery, adopted by the Resolution of the Ministry of Communications and Informatization of the Republic of Belarus of 17 September 2007 № 32 (National Register of Legal Acts of the Republic of Belarus, 2007, number 239, 8/17153);

- if the publication is not included in the catalog, it must be distributed by email of registry, which is approved by the editorial board or editorial publishing council.

At the same time control is exercised over the quality of scientific publications.

For this purpose Higher Certification Commission at least once half a year carries out review of the list and makes changes and additions where they are necessary. The grounds for exclusion of scientific publications from the list or exclusion of certain branches of science (scientific areas) in accordance with which this publication is on the list, serve a cessation of its release, nonfulfillment of requirements of paragraph 4 of the Instruction or the conclusion of the expert council of the Higher Certification Commission about unsatisfactory review published in its articles about its low academic values.

A scientific article must be written at a high scientific level and comply with the following.

A scientific article is a complete and logical product devoted to a particular matter within the range of problems (tasks) that can be solved by the applicant of a scientific degree in the performance of the research. The scientific article discloses the most significant results obtained by the applicant of the degree requiring detailed exposition and argumentation. The scope of scientific articles should be at least 0.35 author's sheet (14 000 printed characters, including spaces between words, punctuation, numbers, etc.), if it is permitted by the rules established for the authors by the respective publications.

Scientific articles published in periodicals included on the list of scientific editions of the Republic of Belarus include (unless otherwise specified by the rules which are laid down for the authors of the respective printed edition) the following elements: annotation; surname and initials of the author (authors) of the article, the title of the article; introduction; the main part, including graphics and other illustrative materials (if any); conclusion, clearly formulated conclusions; a list of cited sources; the date of the receipt of the article in the editorial board printed edition. Additionally, in accordance with the requirements of the editorial boards of scientific publications in the structure of the article may also be included: the list of accepted symbols and abbreviations; annotation in English and (or) any other foreign language. The title of the article should reflect the basic idea of the research, be brief and contain keywords. The annotation should clearly expound the content of the article and be suitable for publication in the annotations to the journals separately from the article. In the introduction there is a brief review of the literature on the given problem, previously indicated unresolved issues, formed and justified purpose of the work and, if it is necessary, it should indicate its connection with important scientific and practical directions. Analysis of the sources used in the preparation of the scientific article should indicate knowledge of the author (authors) of the scientific advances in the field. Mandatory are references to the work of other authors, including foreign publications in this area (if any). In assessing the fulfillment of requirements for publication of the researches results of a dissertation are taken into account: Articles published in the periodicals of the Republic of Belarus included on the list scientific publications of the Republic of Belarus for release of the researches results of dissertations (hereinafter the List).

The results of the rating of scientific publications included on the List of Higher Certification Commission look as follows:

1. Bulletin of the Constitutional Court of the Republic of Belarus.

2. Vestnik BSU. Series 3: History. Economics. Law.

3. The Justice of Belarus.

4. Vesnik of Court.

5. Bulletin of the Academy of the Interior Ministry.

6. Law and Order. 
7. Pravo.by.

8. Law and Democracy.

9. Issues of criminology, criminalistics and forensic expertise.

10. Proceeding of the National Academy of Sciences of Belarus. Humanitarian series.

11. Research Papers of the Academy of Public Administration under the aegis of the President of the Republic of Belarus.

12. Proceedings of the National Security Institute of the Republic of Belarus.

13. Vesnik of Yanka Kupala State University of Grodno. Series 4. Jurisprudence .

14. Doklady of the National Academy of Sciences of Belarus.

15. The problems of strengthening the rule of law: Science, Practice, Trends.

16. Vesnik of Belarus State Economic University.

17. Industrial and commercial law.

18. Journal of International Law and International Relations.

19. Law in Modern Belarusian Society.

20. Proceedings of the Belarusian State Economic University.

21. Economy, law and management problems.

22. Proceedings of the Faculty of International Relations.

23. The Brest University Journal. The Series of Humanities and Social Sciences.

24. Problems of management. Series B (philosophical sciences, jurisprudence, political science).

25. Work. Unions. Society.

26. Socio-economic and legal researches.

27. Belarusian Historical Review.

28. Intellectual Property in Belarus.

29. Actual problems of international public and private international law.

30. Actual problems of science of the XXI century: a collection of scientific papers of young scientists.

31. Vestnik MDU named A.A. Kuliashova. Series D. Economics, Sociology, Law.

32. Proceedings of the Gomel State University named Skaryna. Socio-economic and social sciences.

33. Journal of the Polotsk State University. Series D. Economic and jurisprudence.

34. Bar.GU. Herald Series "Historical sciences and archeology. Economics. Jurisprudence ".

For example, we give a brief description of selected journals:

\section{$\underline{\text { Scientific and practical journal }}$}

"Pravo.by"

In the journal articles are published by leading scientists, practitioners, teachers, graduate students, undergraduates and they highlight current issues of theory and practice of legal activity. The journal is included on the List of scientific editions of the Republic of Belarus by the Higher Certification Commission for the publication of the results of dissertation research in legal sciences. Since 2014 the journal has been included in scientometric database "Russian Science Citation Index" (RSCI), which has about a million registered readers from countries all over the world. Scientific articles are placed in the RSCI due to the number of the article uses, which improves the ranking of scientific citing authors and their materials.

\section{"Vesnik of Yanka Kupala State University of Grodno. Series 4. Jurisprudence"}

For Authors:

\section{Articles acceptance procedure}

1. Authors of the articles are postgraduate students, lecturers, research fellows, people working for a degree of doctor, working or studying at institutions of higher education of the Republic of Belarus and abroad. In other cases, the decision about articles acceptance is made by the editorial board.

2. People without a scientific degree should present an extract from the department meeting minutes with the recommendation for publication. In postgraduates' extract the year of studying must be indicated.

3. Editorial board has the right to ask for the extract from the department meeting minutes containing the recommendation for publication if it is necessary.

4. The author may bring the article with all application documents to the editorial office personally, or send it by post as a usual letter (foreign authors (neighboring and distant foreign countries) are allowed to e-mail all the materials: vesnik@grsu.by).

5. The articles sent to the journals' editorial board are reviewed by the editor-in-chief, executive editor and executive secretary in two-week term to check if the articles correspond to the journal's profile and meets preparation demands and are registered afterwards in accordance with the procedure. (The 
materials, rejected in the reviewing procedure are not returned to the authors).

6. Editorial board does not accept articles published previously in other journals and scientific editions.

7. Publication is free.

8. Royalties are not paid out.

9. Manuscripts and materials in electronic form are not returned to the authors.

\section{Guidelines for Authors}

The manuscript includes the following items:

1. UDC (Universal Decimal Classification) index. Font Times New Roman 10 pt, capital letters, left alignment.

2. Initials and author (authors) second name(s). Font size $10 \mathrm{pt}$, centre alignment in small letters.

3. The title of the publication (font size $12 \mathrm{pt}$ in small letters centre alignment) should reflect the man idea of the research carried out, be concise and contain the keywords, which help to index the article.

4. Summary in Russian contains 200-250 words (font size $9 \mathrm{pt}$ ). The summary besides a brief content of the article should reflect the aim of the scientific work, scientific novelty and application sphere. Summary should also contain a list of keywords. Keywords (5-9) should be presented in Nominative case, typed in small letters in a line with commas between them.

For scientific articles of postgraduate students we also recommend to attach an annotation in the language of the material published, volume 100-150 words (font size $9 \mathrm{pt}$, width alignment), according to the Higher Attestation Commission (HAC, Russian: BAK, Latin: VAK) requirements.

5. The main body should be structured according to the Higher Attestation Commission requirements for scientific articles, published in editions included in the List of scientific editions for thesis research results publishing: introduction, containing a short review of literature on this issue, a circle of problems not solved before; the main part with detailed coverage of questions discussed; the conclusion should contain brief results obtained.

6. List of accepted signs and the abbreviations (if any). Font size $10 \mathrm{pt}$, in small letters, width alignment.

7. List of references (cited literature) is given at the end of the article. It is to correspond to the requirements of GOST 7.1-2003 and Decree of Higher Attestation Commission 15 August 2007: font size $9 \mathrm{pt}$, width alignment. References to unpublished works are forbidden. References to the cited literature are numbered in the sequence of their appearance in the text in square brackets, ex.: [1, p. 32], [2, p. 52-53].

Biography samples are given on the web site http:// www.vesnik.grsu.by/?p=autor\&lang=en.

8. Summary in English contains 200-250 words (with keywords) (font size $9 \mathrm{pt}$ ).

\section{Requirements for the page layout}

1. Font 10 pt., width alignment, with the author's marking the necessary parts of the text using software fonts «Bold», «Italic». The whole text is typed using font «Times New Roman». Single line spacing.

2. Page parameters: size A4; margins: left and top 25 $\mathrm{mm}$, right and bottom $-20 \mathrm{~mm}$, page numbers at the top of the page beginning with the second page, right alignment. Indentation $-12 \mathrm{~mm}$

3. It is not allowed to use two and more symbols «space» in succession, also indentations, spaces between a word and a symbol «full stop», «comma», «inverted comma», «bracket». In typing texts should be used double angle brackets («»), in typing English-language texts should be used universal quotation mark ("').

4. All values and simple formulas in the text and tables should be typed as text elements but not as objects of use of the formula editor. Complex formulas are typed using application MathType (size $10 \mathrm{pt}$ ). Formulae shouldn't exceed $120 \mathrm{~mm}$ in width. While carrying over a part of a formula to the following line the mathematical sign should be repeated at the beginning of the following line. Drawings should be made in a vector CorelDRAW or Photoshop. Illustrations (B\&W) should be clear and of good quality (resolution of the originals - $300 \mathrm{dpi}$ ). Print signs and labels under illustrations - Times New Roman, non-fat, 9 pt. The maximum illustrations width should not exceed $170 \mathrm{~mm}$, maximum height - $220 \mathrm{~mm}$ (with captions). All tables, charts and diagrams should be embedded in the text and have a connection (to be available for editing) with the program source code, in which they were created (Excel, Corel Draw). Quality of illustrations correspond to the quality of original illustrations that are given to the editorial office.

5. Tables (if any). Font size $9 \mathrm{pt}$, table name lover case letters, $10 \mathrm{pt}$, width alignment; table size in width shouldn't exceed $140 \mathrm{~mm}$. 
6. The use of automatic end and footnotes is not allowed.

\section{General requirements for the article}

1. Manuscripts should be submitted in paper having not fewer than 14000 printing symbols in 2 copies and in electronic form in editor MS Word. The articles are published in Belarusian and Russian. The articles are accepted also in Polish, English and German (published in original).

2. The manuscript of the article must be signed by its author (all authors). It should also contain his agreement for publishing the article in open access on the Internet.

3. The following information should be attached to the manuscript on a separate sheet of paper: author's surname, name and family name in full (in Belarusian, Russian and transliteration in the Roman alphabet (Latin): like in passport); scientific degree, post, place of work, e-mail, address for correspondence, phone number (everything in Russian and English).

4. Postgraduate students should also indicate surname, name, family name, scientific degree, academic status and place of work of their research advisor (everything in Russian and English; surname, name - transliteration in the Roman alphabet (Latin)).

5. There should be attached another summary both in Russian and English on a separate sheet of paper according to the following scheme: UDC, surname, initials of the author, title of the publication, keywords, summary (for control editing of English summary). The authors may also point out scientific speciality (specialities) the theme of the article refers to.

6. Authors bear the responsibility for bringing previously published articles, or articles accepted to be printed in other editions. According to the Law of Publishing authors bear the responsibility for choice and reliability of the given facts, citations, economic and statistic data, proper names (including geographical names) and other encyclopedic information. The Editorial Board has the right to edit the manuscript and abridge it without misrepresenting the paper contents.

7. It is not allowed to make edits and changes in the finished artwork. In case such changes are made the reimposition is made at the author's expense. «Creative» texts' shifts such as texts' replacements, equivalent replacements, full or partial deletion, etc. in the finished artwork are not allowed.

8. Editorial board has the right to change the rules of registration, reviewing, approval (refusal) of the materials received by the editorial board of the scientific (trade) journals «Vesnik of Yanka Kupala State University of Grodno» on the basis of the instructions of Higher Attestation Commission or decisions of editorial boards of journals.

\begin{tabular}{|c|l|}
\hline \multicolumn{2}{|c|}{ Bibliography samples } \\
\hline Resource & \multicolumn{1}{c|}{ Sample } \\
\hline $\begin{array}{c}\text { One, two, or } \\
\text { three authors }\end{array}$ & $\begin{array}{l}\text { Azar, B.S. Fundamentals of English gram- } \\
\text { mar / B.S. Azar. - Second Edition. - New } \\
\text { Jersey: Prentice Hall Regents, 1992. - 398 p. }\end{array}$ \\
\cline { 2 - 3 } & $\begin{array}{l}\text { Azar, B.S. Basic English grammar; teacher } \\
\text { guide / B.S. Azar, B.F. Matthies, S. Harte. - } \\
\text { Second Edition. - New Jersey: Prentice Hall } \\
\text { Regents, 1997. - 184p. }\end{array}$ \\
\hline $\begin{array}{c}\text { Four and more } \\
\text { authors }\end{array}$ & $\begin{array}{l}\text { A University Grammar of English / R, Quirk } \\
\text { and others / redactor I.P. Verkhovskaya. - } \\
\text { M.: Vysshaja Shkola, 1982. - 391 p. }\end{array}$ \\
\hline $\begin{array}{c}\text { Electronic } \\
\text { resources }\end{array}$ & $\begin{array}{l}\text { Britannica 2008 Ultimate Reference Suite } \\
\text { [Electronic Resource]: encyclopedia. - M. : } \\
\text { New Disc 2007. }\end{array}$ \\
\hline $\begin{array}{c}\text { Internet } \\
\text { resources }\end{array}$ & $\begin{array}{l}\text { Proceeding of mini-symposium on biolog- } \\
\text { ical nomenclature in the 21st centry [Elec- } \\
\text { tronic resource] / Ed. J.L. Reveal. - College } \\
\text { Park M.D., 1996. - Mode of access: http:// } \\
\text { www.inform.ind.edu/PBIO/brum.html. - } \\
\text { Date of access: 14.09.2005. }\end{array}$ \\
\hline
\end{tabular}

\section{BIBLIOGRAPHY}

1. Об утверждении Инструкции о порядке формирования перечня научных изданий Республики Беларусь для опубликования результатов диссертационных исследований: Постановление Высшей аттестационной комиссии Республики Беларусь от 8 июня 2009 г. № 3 (в редакции постановления Высшей аттестационной комиссии Республики Беларусь от 30 июня 2012 г. № 5).

2. http://vak.org.by/index.php?go=Pages\&in=view\&id=153.

3. http://csl.bas-net.by/anews1.asp?id=21207.

4. http://plib.unibel.by.

5. http://www.justbel.info.

6. http://vesnik.grsu.by.

7. http://www.bseu.by/russian/scientific/herald.htm 8.http:// www.bsu.by/ru/main.aspx?guid=184131. 